\title{
Application of probiotic Bacillus spp. isolated from African nightcrawler (Eudrilus eugeniae) on Nile Tilapia (Oreochromis niloticus L.)
}

\author{
Samson J. ${ }^{1} *$, Quiazon K.M. ${ }^{12}$, Choresca C. ${ }^{3}$ \\ ${ }^{1}$ College of Fisheries, Central Luzon State University, Science City of Muñoz 3120, Nueva \\ Ecija, Philippines
}

${ }^{2}$ Freshwater Aquaculture Center, Central Luzon State University, Science City of Muñoz 3120, Nueva Ecija, Philippines

${ }^{3}$ National Fisheries Research and Development Institute - Fisheries Biotechnology Center, Bureau of Fisheries and Aquatic Resources - National Freshwater Fisheries Technology Center, Central Luzon State University Compound, Science City of Muñoz 3120, Nueva Ecija, Philippines

Corresponding author's Email: samsonjaypee@clsu.edu.ph 


\begin{abstract}
Due to the emergence of antibiotic-resistant pathogens, probiotics in aquaculture are used for the prevention of infectious microbial diseases and substitute for antibiotics and chemotherapeutics. In this study, we evaluated the effect of probiotic Bacillus spp. isolated from African nightcrawler (Eudrilus eugeniae) on the growth, feed utilization, and disease resistance of Nile tilapia (Oreochromis niloticus). Four probiotic strains of Bacillus spp. (ANSCI9, BFAR9, RM3, and RM10) were individually incorporated in the commercial diet (control) at $10^{8} \mathrm{CFU} \mathrm{g}^{-1}$ of feed. The experimental fish were fed at $5 \%$ of their body weight for 30 days, and subjected to a 14-day Aeromonas hydrophila challenge test afterward. The results showed the probiotic-treated groups have higher $(P<0.05)$ average body weight $(\mathrm{ABW})(4.51 \pm 0.34 \mathrm{~g})$ than the control $(3.89 \pm$ $0.17 \mathrm{~g})$. The BFAR9 $(2.73 \pm 0.26 \mathrm{~g})$ and RM10 $(3.15 \pm 0.30 \mathrm{~g})$ showed higher $(P<0.05)$ absolute growth $(\mathrm{AG})$ than the control $(2.20 \pm 0.16 \mathrm{~g})$. Furthermore, RM10 had higher $(P<0.05)$ specific growth rate $(\mathrm{SGR})\left(1.60 \pm 0.10 \%\right.$ day $\left.^{-1}\right)$ and relative growth rate $(\mathrm{RGR})(181.39 \pm 18.16 \%)$ than the control $\left(\mathrm{SGR}=1.29 \pm 0.07 \% \mathrm{day}^{-1} ; \mathrm{RGR}=129.84 \pm 9.77 \%\right)$. Consequently, RM10 had significantly lower $(P<0.05)$ feed conversion ratio $(\mathrm{FCR})(1.99 \pm 0.13)$ than the control $(2.60 \pm$ $0.16)$. The challenge test revealed that the probiotic-treated groups have higher $(P<0.05)$ survival $(81.25 \pm 9.57 \%)$ than the control $(55.00 \pm 19.15 \%)$. These results revealed that the probiotic Bacillus spp. isolated from E. eugeniae improved the growth, feed utilization, and the disease resistance of Nile tilapia.
\end{abstract}

Keywords: microbiota, Aeromonas hydrophila, earthworms, aquaculture, immunomodulation, disease resistance, feed utilization 


\section{Introduction}

The need for sustainable aquaculture has encouraged exploration into the use of feed additives for growth promotion and health improvement of aquatic organisms (Zokaeifar et al. 2012; Saleh et al. 2015; Michael et al. 2017; Samson 2019b, a). These feed additives such as the probiotic bacteria are used for the growth promotion, pathogen inhibition, enhanced nutrient utilization, water remediation, stress tolerance, and reproduction of aquatic species (Balcazar et al. 2006; Cruz et al. 2012). These beneficial microorganisms can be isolated from various sources, including in food (Leite et al. 2015; Demir and Başbülbül 2017), aquatic organisms (Lin et al. 2013; Lamari et al. 2014; Sanchez-Ortiz et al. 2015), terrestrial animals (Brashears et al. 2003; Musikasang et al. 2009; Jena et al. 2013; Feng et al. 2017), and humans (Amenu 2015; Reis et al. 2016). In this study, we evaluated the probiotic potential of the isolated Bacillus spp. from earthworms on Nile tilapia. Although some studies have used earthworms as a protein source for fish (Boaru et al. 2016; Mohanta et al. 2016), and explored the presence of microorganisms in them (Horn et al. 2003; Singleton et al. 2003; Kim et al. 2004; Byzov et al. 2009), to the best of our knowledge, no study has demonstrated the effect of these microorganisms on aquatic species.

The gut of earthworms provides an ideal and favorable environment for the growth and activity of bacteria (Govindarajan and Prabaharan 2015). For several centuries, China and other parts of the Far East believed that earthworms promote overall health, and are sources of therapeutic drugs for various diseases (El-Kamali 2000; Ismail 2005). Furthermore, indigenous people all over the world, more particularly in Asia, including Vietnam, China, Korea, India, and Myanmar, extract and use the biologically active compounds from earthworms (Ranganathan 2006). Unfortunately, there is no available information on the application of probiotic bacteria from earthworms, specifically on aquaculture. Hence, in this present study, we aimed to evaluate the effect of probiotic Bacillus spp. isolated from E. eugeniae on the growth, feed utilization, and disease resistance of Nile tilapia.

\section{Materials and Methods}

\section{Source of Bacteria}

Four probiotic strains of Bacillus spp. (ANSCI9, BFAR9, RM3, and RM10) previously isolated from E. eugeniae were used in this study (Samson et al. 2020). The 16s rRNA sequences of the probiotic isolates are available in the GenBank, with accession numbers: MH919310, MH919302, MH919306, and MH919308. 


\section{Experimental Diets and Design}

A commercial diet (Tateh Aquafeeds, Philippines) served as the basal diet (control). The proximate composition was as follows: crude protein $31 \%$, lipid $5 \%$, crude fiber $8 \%$, and crude ash $12 \%$. The probiotic-treated diets were prepared to contain a single strain of Bacillus spp. (ANSCI9, BFAR9, RM3, and RM10) per group. The McFarland standard was used to estimate the bacterial densities. Dilutions were done using phosphate buffer solution (PBS) to have a similar bacterial density. The isolates were sprayed on commercial feeds $\left(10^{8} \mathrm{CFU} \cdot \mathrm{g}^{-1}\right)$ and air-dried for 2 hours before storing at $4^{\circ} \mathrm{C}$.

Four hundred $O$. niloticus fingerlings were distributed into 20 glass aquaria $(52 \times 25 \times 30$ $\mathrm{cm}$ ) divided into five experimental groups (four replicates per group). Each group consists of 80 fish (20 fish $\times 4$ aquaria), which had an initial weight of $1.76 \pm 0.07 \mathrm{~g}$. The water quality parameters during the study were the following: the temperature at $25.3 \pm 0.9^{\circ} \mathrm{C}, \mathrm{pH}$ at $8.0 \pm 0.2$, and dissolved oxygen at $3.52 \pm 1.16 \mathrm{ppm}$. The fish were fed their respective diets (at approximately $5 \%$ of body weight day $^{-1}$ ) thrice daily at 8:00, 12:00, and 16:00 for 30 days.

\section{Data Collection}

At the end of the feeding trial, all fish were measured and weighed. Growth parameters and survival rate were measured as follows:

Specific growth rate $(\mathrm{SGR})=\frac{(\ln [\text { final weight }]-\ln [\text { initial weight }])}{(\text { time interval in days })} \times 100$

$$
\text { Relative growth rate }(\mathrm{RGR})=\frac{\text { Final weight of fish }- \text { Initial weight of fish }}{\text { Initial weight of fish }} \times 100
$$

$$
\begin{gathered}
\mathrm{AG}(\mathrm{g})=\text { Final weight }- \text { Initial weight } \\
\mathrm{FCR}=\frac{\text { Amount of feed given }(\mathrm{g})}{\text { Weight gain }(\mathrm{g})} \\
\mathrm{SR}(\%)=\frac{\text { No. of individuals at the end of the experiment }}{\text { No of individuals at the beginning of the study }} \times 100
\end{gathered}
$$

\section{Challenge Test}

O. niloticus fingerlings $(4.39 \pm 0.40 \mathrm{~g})$ were challenged with A. hydrophila (BIOTECH 10089) after the 30-day feeding trial. Fish were anesthetized in tricaine methanesulfonate (MS222) 
solution and intramuscularly injected with $0.1 \mathrm{~mL}$ A. hydrophila suspension $\left(10^{7} \mathrm{CFU} \cdot \mathrm{mL}^{-1}\right)$. The mortality was observed daily until the $14^{\text {th }}$ day, and the relative level of protection (RLP) among the challenged fish was determined using the equation: [100 - (immunized mortality\% / control mortality\%)] × 100 (Ruangroupan et al. 1986)

\section{Statistical Analysis}

Results were subjected to a one-way analysis of variance (ANOVA), followed by Duncan's Multiple Range Test (DMRT) at a significant level of $P<0.05$ when there was a significant difference among the treatments.

\section{Results}

\section{Growth Performance}

The summary of the measurements and growth parameters of the experimental fish is shown in Table 1. The treatments supplemented with probiotic Bacillus spp. showed higher $(P<0.05)$ ABW than the control. RM10 gained the highest ABW $(4.88 \pm 0.30 \mathrm{~g})$ among the treatments; whereas, the lowest was recorded from the control group $(3.89 \pm 0.17 \mathrm{~g})$. Treatments RM10 (6.91 $\pm 0.23 \mathrm{~cm})$, BFAR9 $(6.88 \pm 0.07 \mathrm{~cm})$, and RM3 $(6.65 \pm 0.19 \mathrm{~cm})$ have significantly higher $(P<0.05)$ lengths than the control $(6.16 \pm 0.11 \mathrm{~cm})$. Also, treatment RM10 had significantly higher $(P<0.05)$ SGR $\left(1.60 \pm 0.10 \%\right.$ day $\left.^{-1}\right)$ and RGR $(181.39 \pm 18.16 \%)$ than the control $\left(\mathrm{SGR}=1.29 \pm 0.07 \%\right.$ day $\left.^{-1} ; \mathrm{RGR}=129.84 \pm 9.77 \%\right)$. In addition, treatments BFAR9 $(2.73 \pm 0.26$ g) and RM10 (3.15 $\pm 0.30 \mathrm{~g})$ showed significantly higher $(P<0.05)$ AG than the control $(2.20 \pm$ $0.16 \mathrm{~g})$. Consequently, treatment RM10 had significantly lower $(P<0.05)$ FCR $(1.99 \pm 0.13)$ than the control $(2.60 \pm 0.16)$. While no significant difference was observed on the survival of the treatments. 
Table 1. Summary (Mean \pm SD) of measurements and growth parameters of the experimental fish $(\mathrm{n}=4)$.

\begin{tabular}{lccccc}
\hline & \multicolumn{4}{c}{ TREATMENTS } \\
\cline { 2 - 6 } & Control & ANSCI9 & BFAR9 & RM3 & RM10 \\
\hline Initial ABW $(\mathrm{g})$ & $1.69 \pm 0.04^{\mathrm{a}}$ & $1.80 \pm 0.07^{\mathrm{a}}$ & $1.78 \pm 0.09^{\mathrm{a}}$ & $1.77 \pm 0.08^{\mathrm{a}}$ & $1.74 \pm 0.02^{\mathrm{a}}$ \\
Initial Length (cm) & $4.63 \pm 0.21^{\mathrm{a}}$ & $4.59 \pm 0.12^{\mathrm{a}}$ & $4.82 \pm 0.24^{\mathrm{a}}$ & $4.67 \pm 0.10^{\mathrm{a}}$ & $4.66 \pm 0.08^{\mathrm{a}}$ \\
Final ABW (g) & $3.89 \pm 0.17^{\mathrm{c}}$ & $4.31 \pm 0.20^{\mathrm{b}}$ & $4.51 \pm 0.21^{\mathrm{ab}}$ & $4.34 \pm 0.35^{\mathrm{b}}$ & $4.88 \pm 0.30^{\mathrm{a}}$ \\
Final Length (cm) & $6.16 \pm 0.11^{\mathrm{c}}$ & $6.18 \pm 0.04^{\mathrm{c}}$ & $6.88 \pm 0.07^{\mathrm{a}}$ & $6.65 \pm 0.19^{\mathrm{b}}$ & $6.91 \pm 0.23^{\mathrm{a}}$ \\
AG (g) & $2.20 \pm 0.16^{\mathrm{c}}$ & $2.51 \pm 0.23^{\mathrm{bc}}$ & $2.73 \pm 0.26^{\mathrm{b}}$ & $2.57 \pm 0.35^{\mathrm{bc}}$ & $3.15 \pm 0.30^{\mathrm{a}}$ \\
SGR (\% day $\left.{ }^{-1}\right)$ & $1.29 \pm 0.07^{\mathrm{b}}$ & $1.35 \pm 0.11^{\mathrm{b}}$ & $1.44 \pm 0.13^{\mathrm{ab}}$ & $1.39 \pm 0.14^{\mathrm{b}}$ & $1.60 \pm 0.1^{\mathrm{a}}$ \\
RGR (\%) & $129.84 \pm 9.77^{\mathrm{b}}$ & $139.71 \pm 16.82^{\mathrm{b}}$ & $153.16 \pm 21.1^{\mathrm{ab}} 145.61 \pm 22.44^{\mathrm{b}}$ & $181.39 \pm 18.16^{\mathrm{a}}$ \\
FCR & $2.60 \pm 0.16^{\mathrm{a}}$ & $2.47 \pm 0.23^{\mathrm{a}}$ & $2.30 \pm 0.21^{\mathrm{ab}}$ & $2.41 \pm 0.31^{\mathrm{ab}}$ & $1.99 \pm 0.13^{\mathrm{b}}$ \\
SR (\%) & $95.00 \pm 5.77^{\mathrm{a}}$ & $87.50 \pm 25.00^{\mathrm{a}}$ & $97.50 \pm 2.89^{\mathrm{a}}$ & $97.50 \pm 5.00^{\mathrm{a}}$ & $91.25 \pm 14.36^{\mathrm{a}}$ \\
\hline
\end{tabular}

Note: Treatments with the same superscript are not significantly different at $P<0.05$.

\section{Challenge Test}

The cumulative mortality of the experimental groups was recorded daily until the $14^{\text {th }}$ day (Fig 1). All treated groups showed significantly higher $(P<0.05)$ survival rates rate $(81.25 \pm 9.57$ $\%)$ than the control $(55.00 \pm 19.15 \%)$. Treatment RM10 had the highest survival rate $(85.0 \pm 10.00$ $\%)$ among the treatments, while the lowest was recorded on the control $(55 \pm 19.15 \%)$. The RLP of the treated groups is $\geq 50 \%$ with the highest value in RM10 (66.67\%) while the lowest for RM3 $(50.00 \%)$. The result of the challenge test is presented in Table 3.

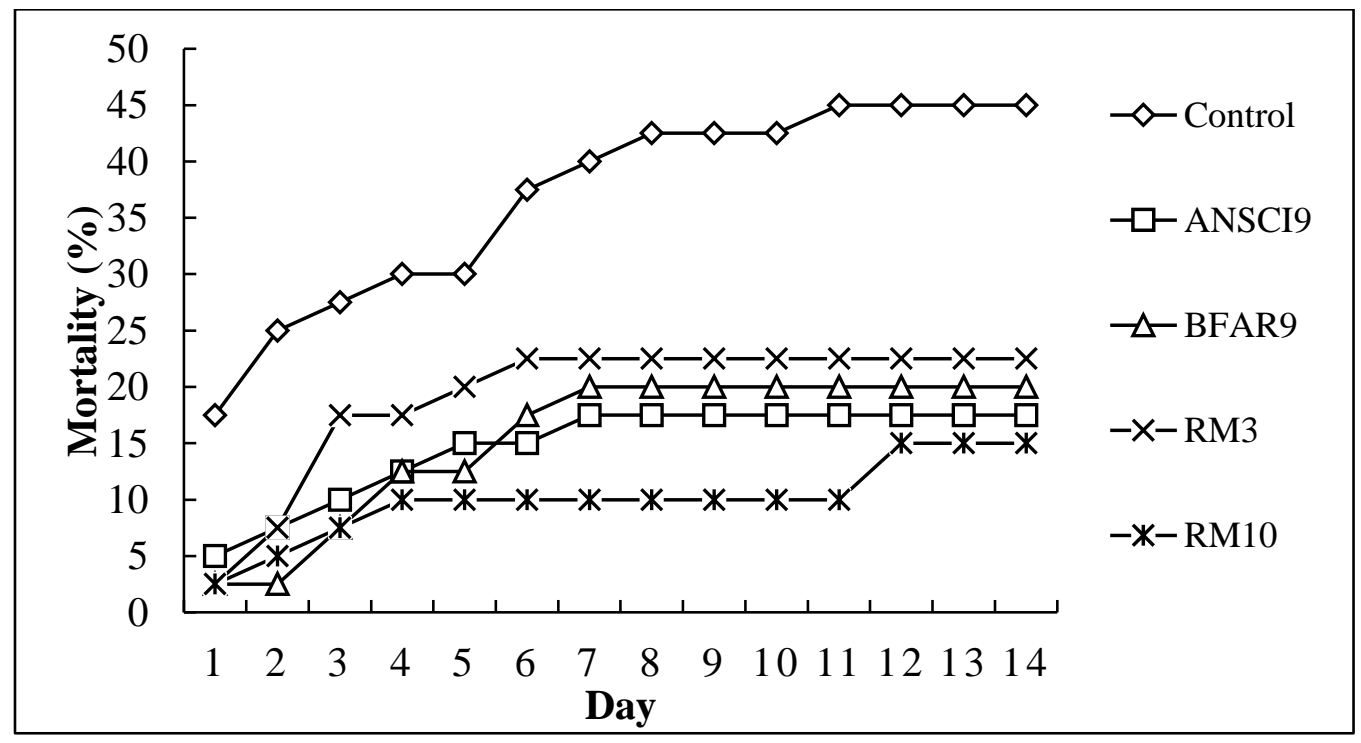

Figure 1. Cumulative mortality of each treatment during the A. hydrophila challenge test 
Table 3. Values (Mean \pm SD) of SR RLP for each treatment after challenging with A. hydrophila.

\begin{tabular}{lccccc}
\hline \hline \multicolumn{5}{c}{ TREATMENTS } \\
\hline CR $(\%)$ & $55.0 \pm 19.15^{\mathrm{b}}$ & $82.5 \pm 8.16^{\mathrm{a}}$ & $80.0 \pm 10.00^{\mathrm{a}}$ & $77.5 \pm 20.82^{\mathrm{a}}$ & $85.0 \pm 10.00^{\mathrm{a}}$ \\
RLP $(\%)$ & 0.0 & 61.11 & 55.56 & 50.00 & 66.67 \\
\hline \hline
\end{tabular}

Note: Treatments with the same superscript are not significantly different at $P<0.05$.

\section{Discussion}

The beneficial effect of probiotic Bacillus spp. isolated from E. eugeniae was observed in this study. Nile tilapia showed better growth when fed with probiotics. Previous studies have reported similar results on the effect of Bacillus spp. on the growth and survival of Nile tilapia. Soltan et al., (2016) reported that commercial probiotics containing allicin, high unit hydrolytic enzyme, Bacillus subtilis spores, and ginseng extract improved the growth and feed utilization of Nile tilapia. Similarly, Bacillus pumilus improved the growth performance of Nile tilapia due to enhanced immune system, health status, and disease resistance (Aly et al. 2008). Furthermore, the application of Bacillus coagulans and other Bacillus spp. in the water also enhanced the growth and immune response of Nile tilapia (Zhou et al. 2009; Sutthi et al. 2018). According to Buruian et al. (2014), the application of probiotic Bacillus spp. in the aquaculture system improves the growth performance, immune response, disease resistance, and survival of the fish. These probiotics produce extracellular enzymes (proteases, amylases, and lipases), and provide vitamins, fatty acids, and amino acids that have a beneficial effect on the metabolism of aquatic animals (Balcazar et al. 2006). The observed growth improvement of treated groups can be a result of improved enzymatic activity on the fish gut, as the probiotics used in the experiment produce extracellular enzymes. These extracellular enzymes aids in breaking down food molecules, which makes the absorption of nutrients more efficient (EL-Haroun et al. 2006). In contrast, Silva et al. (2015) reported that the addition of Bacillus amyloliquefaciens did not improve the growth and proximal composition of Nile tilapia; however, they observed a significant increase of villi height and number of goblet cells in the intestine. Their result suggests that the digestion and nutrient absorption of fish had been improved. Similarly, Shelby et al. (2006) observed no significant improvement in growth; but they recorded higher survival rates after 39 to 63 days of probiotic application. As we noted in this study, only RM10 showed significantly better SGR, RGR, and FCR; although the probiotics used are of the same genus (i.e., Bacillus) and source (i.e., E. 
eugeniae). This result does not imply that the three probiotic isolates (i.e., ANSCI9, BFAR9, RM3) are less efficient. In fact, all probiotic-treated groups showed higher survival rates when challenged with A. hydrophila. This suggests that the effect of the probiotics may not be observed on growth but rather to the immunity and intestinal morphology of the fish. Thus, it is better to evaluate the effect of these probiotics in the immunological parameters and intestinal morphology of the fish. Furthermore, this observation also suggests that the effects of probiotics application differs from each bacterial species and strain. Correspondingly, it is important to measure the effective rate of application for each probiotic bacterium.

In this study, higher survival rates of probiotic-treated groups infected with A. hydrophila was recorded. Similar results were reported by Selim and Reda (2015); they reported that dietary supplementation of $B$. amyloliquefaciens improved the survival of Nile tilapia infected with Yersinia ruckeri or Clostridium perfringens type D. Moreover, Gupta et al. (2014) also observed an improvement in the survival of Cyprinus carpio fry fed with probiotics and challenged with $A$. hydrophila. In our study, the improvement of survival rates of the probiotic-treated groups is attributed to the ability of probiotics to enhance the immune system. It is a result of immunity modulation or immunomodulation, which is one of the common health benefits credited to the application of probiotics (Cross 2002). It is well-known that probiotics may lessen the occurrence of disease or decrease the danger of disease outbursts. One possible mechanism for this is the prevention of pathogen colonization on the intestinal mucosa or other epithelial surfaces; as probiotic strains colonize these surfaces (Balcazar et al. 2006). Furthermore, they can also produce inhibitory substances against pathogenic organisms and compete for essential nutrients (Ring $\varnothing$ and Gatesoupe 1998). The spore-forming ability of the Bacillus spp. used in this study may perhaps aid in administering their effect. This ability increases their chance to survive the harsh conditions in the intestine and the activities of the digestive enzymes. To further explore the beneficial effects of these probiotic bacteria, we suggest assessing their effects on the biochemical and hematological parameters of the fish. Additionally, the ability of these probiotics in preventing the infection of other pathogenic bacteria should also be considered.

\section{Conclusion}

This study is the first report on the application of probiotic Bacillus spp. isolated from $E$. eugeniae in fish. The results of this study revealed the beneficial effect of Bacillus spp. isolated from E. eugeniae on the growth performance, feed utilization and disease resistance of Nile tilapia. 


\section{Acknowledgement}

The authors acknowledge the financial support from the Department of Science and Technology - Accelerated Science and Technology Human Resource Development Program (DOST-ASTHRDP). Also, the authors acknowledge the assistance from the Fisheries Biotechnology Center, College of Fisheries, and Freshwater Aquaculture Center, CLSU. 


\section{References}

Aly SM, Mohamed MF, John G (2008) Effect of probiotics on the survival, growth and challenge Infection in Tilapia nilotica (Oreochromis niloticus). Aquac Res 39:647-656. https://doi.org/10.1111/j.1365-2109.2008.01932.x

Amenu D (2015) Probiotic Properties of Lactic Acid Bacteria from Human Milk. J Med Microbiol Diagn s3:. https://doi.org/10.4172/2161-0703.S3-005

Balcazar J, Blas I, Ruizzarzuela I, et al (2006) The role of probiotics in aquaculture. Vet Microbiol 114:173-186. https://doi.org/10.1016/j.vetmic.2006.01.009

Boaru A, Struți D, Dărăban SV, Georgescu B (2016) The effect of using earthworm meal (Eisenia foetida) as protein supplement for the growth of Xiphophorus hellerii juveniles. Poeciliid Res 6:4-9

Brashears MM, Jaroni D, Trimble J (2003) Isolation, selection, and characterization of lactic acid bacteria for a competitive exclusion product to reduce shedding of Escherichia coli O157:H7 in Cattle. J Food Prot 66:355-363. https://doi.org/10.4315/0362-028X-66.3.355

Buruian C-T, Profir AG, Vizreanu C (2014) Effects of probiotic Bacillus species in aquaculture an overview. Food Technol 38:9-17

Byzov BA, Nechitaylo TYu, Bumazhkin BK, et al (2009) Culturable microorganisms from the earthworm digestive tract. Microbiology 78:360-368.

https://doi.org/10.1134/S0026261709030151

Cross M (2002) Microbes versus microbes: immune signals generated by probiotic lactobacilli and their role in protection against microbial pathogens. FEMS Immunol Med Microbiol $34: 245-253$

Cruz PM, Ibáñez AL, Monroy Hermosillo OA, Ramírez Saad HC (2012) Use of probiotics in aquaculture. ISRN Microbiol 2012:1-13. https://doi.org/10.5402/2012/916845

Demir E, Başbülbül G (2017) Screening of bacteriocin production in lactic acid bacteria isolated from fermented dairy products. Biotechnol J Int 18:1-9. https://doi.org/10.9734/BJI/2017/33504

EL-Haroun ER, Goda AMA-S, Kabir Chowdhury MA (2006) Effect of dietary probiotic Biogen ${ }^{\circledR}$ supplementation as a growth promoter on growth performance and feed utilization of Nile tilapia Oreochromis niloticus (L.). Aquac Res 37:1473-1480. https://doi.org/10.1111/j.1365-2109.2006.01584.x

El-Kamali HH (2000) Folk medicinal use of some animal products in Central Sudan. J Ethnopharmacol 72:279-282

Feng Y, Qiao L, Liu R, et al (2017) Potential probiotic properties of lactic acid bacteria isolated from the intestinal mucosa of healthy piglets. Ann Microbiol 67:239-253. https://doi.org/10.1007/s13213-017-1254-6 
Govindarajan B, Prabaharan V (2015) Gut bacterial load analysis of earthworms (Eudrilus eugeniae)-a controlled laboratory study. Eur J Environ Ecol 2:38-43

Gupta A, Gupta P, Dhawan A (2014) Dietary supplementation of probiotics affects growth, immune response and disease resistance of Cyprinus carpio fry. Fish Shellfish Immunol 41:113-119. https://doi.org/10.1016/j.fsi.2014.08.023

Horn MA, Schramm A, Drake HL (2003) The Earthworm Gut: an Ideal Habitat for Ingested N2O-Producing Microorganisms. Appl Environ Microbiol 69:1662-1669. https://doi.org/10.1128/AEM.69.3.1662-1669.2003

Ismail SA (2005) The Earthworm Book. Other India Press, Mapusa, Goa

Jena PK, Trivedi D, Thakore K, et al (2013) Isolation and characterization of probiotic properties of Lactobacilli isolated from rat fecal microbiota. Microbiol Immunol 57:407-416. https://doi.org/10.1111/1348-0421.12054

Kim H-J, Shin K-H, Cha C-J, Hur H-G (2004) Analysis of aerobic and culturable bacterial community structures in earthworm (Eisenia fetida) intestine. Agric Chem Biotechnol 47:137-142

Lamari F, Sadok K, Bakhrouf A, Gatesoupe F-J (2014) Selection of lactic acid bacteria as candidate probiotics and in vivo test on Artemia nauplii. Aquac Int 22:699-709. https://doi.org/10.1007/s10499-013-9699-5

Leite AMO, Miguel MAL, Peixoto RS, et al (2015) Probiotic potential of selected lactic acid bacteria strains isolated from Brazilian kefir grains. J Dairy Sci 98:3622-3632. https://doi.org/10.3168/jds.2014-9265

Lin Y-H, Chen Y-S, Wu H-C, et al (2013) Screening and characterization of LAB-produced bacteriocin-like substances from the intestine of grey mullet (Mugil cephalus L.) as potential biocontrol agents in aquaculture. J Appl Microbiol 114:299-307. https://doi.org/10.1111/jam.12041

Michael FR, Saleh NE, Shalaby SM, et al (2017) Effect of different dietary levels of commercial wood charcoal on growth, body composition and environmental loading of red tilapia hybrid. Aquac Nutr 23:210-216. https://doi.org/10.1111/anu.12385

Mohanta KN, Subramanian S, Korikanthimath VS (2016) Potential of earthworm (Eisenia foetida) as dietary protein source for rohu (Labeo rohita) advanced fry. Cogent Food Agric 2:. https://doi.org/10.1080/23311932.2016.1138594

Musikasang H, Tani A, H-kittikun A, Maneerat S (2009) Probiotic potential of lactic acid bacteria isolated from chicken gastrointestinal digestive tract. World J Microbiol Biotechnol 25:1337-1345. https://doi.org/10.1007/s11274-009-0020-8

Ranganathan LS (2006) Vermibiotechnology: from soil health to human health. Agrobios (India) 
Reis NA, Saraiva MAF, Duarte EAA, et al (2016) Probiotic properties of lactic acid bacteria isolated from human milk. J Appl Microbiol 121:811-820. https://doi.org/10.1111/jam.13173

Ring $\varnothing$ E, Gatesoupe F (1998) Lactic acid bacteria in fish. Aquaculture 160:177-20

Ruangroupan L, Kitao T, Yoshida T (1986) Protective efficacy of Aeromonas hydrophila vaccines in Nile tilapia. Vet Immunol Immunopathol 12:345-350

Saleh NE, Michael FR, Toutou MM (2015) Evaluation of garlic and onion powder as phytoadditives in the diet of sea bass (Dicentrarcus labrax). Egypt J Aquat Res 41:211-217. https://doi.org/10.1016/j.ejar.2015.03.008

Samson JS (2019a) Oral Administration of Pulverized Wood Charcoal on Growth, Feed Utilization, Survival and Waste Excretion of Red Tilapia (Oreochromis sp.). Int J Trend Sci Res Dev 3:417-421. https://doi.org/10.31142/ijtsrd23724

Samson JS (2019b) Effect of garlic (Allium sativum) supplemented diets on growth, feed utilization and survival of red tilapia (Oreochromis sp.). Int J Agric Technol 15:637-644

Samson JS, Choresca CH, Quiazon KMA (2020) Selection and screening of bacteria from African nightcrawler, Eudrilus eugeniae (Kinberg, 1867) as potential probiotics in aquaculture. World J Microbiol Biotechnol 36:16. https://doi.org/10.1007/s11274-0192793-8

Sanchez-Ortiz AC, Luna-Gonzalez A, Campa-Cordova AI, et al (2015) Isolation and characterization of potential probiotic bacteria from pustulose ark (Anadara tuberculosa) suitable for shrimp farming. Lat Am J Aquat Res 43:123-136. https://doi.org/10.3856/vol43-issue1-fulltext-11

Selim KM, Reda RM (2015) Improvement of immunity and disease resistance in the Nile tilapia, Oreochromis niloticus, by dietary supplementation with Bacillus amyloliquefaciens. Fish Shellfish Immunol 44:496-503. https://doi.org/10.1016/j.fsi.2015.03.004

Shelby RA, Lim C, Yildirim-Aksoy M, Delaney MA (2006) Effects of probiotic diet supplements on disease resistance and immune response of young Nile tilapia, Oreochromis niloticus. J Appl Aquac 18:23-34. https://doi.org/10.1300/J028v18n02_02

Silva TFA, Petrillo TR, Yunis-Aguinaga J, Fernandes P (2015) Effects of the probiotic Bacillus amyloliquefaciens on growth performance, hematology and intestinal morphometry in cage-reared Nile tilapia. Lat Am J Aquat Res 43:963-971. https://doi.org/10.3856/vol43issue5-fulltext-16

Singleton DR, Hendrix PF, Coleman DC, Whitman WB (2003) Identification of uncultured bacteria tightly associated with the intestine of the earthworm Lumbricus rubellus (Lumbricidae; Oligochaeta). Soil Biol Biochem 35:1547-1555. https://doi.org/10.1016/S0038-0717(03)00244-X 
Soltan MA, Fouad IM, Elfeky A (2016) Growth and feed utilization of Nile tilapia, Oreochromis niloticus fed diets containing probiotic. Glob Vet 17:442-450.

https://doi.org/10.5829/idosi.gv.2016.442.450

Sutthi N, Thaimuangphol W, Rodmongkoldee M, et al (2018) Growth performances, survival rate, and biochemical parameters of Nile tilapia (Oreochromis niloticus) reared in water treated with probiotic. Comp Clin Pathol. https://doi.org/10.1007/s00580-017-2633-x

Zhou X, Tian Z, Wang Y, Li W (2009) Effect of treatment with probiotics as water additive on tilapia (Oreochromis niloticus) growth performance and immune response. Fish Physiol Biochem 36:501-9. https://doi.org/10.1007/s10695-009-9320-z

Zokaeifar H, Balcázar JL, Saad CR, et al (2012) Effects of Bacillus subtilis on the growth performance, digestive enzymes, immune gene expression and disease resistance of white shrimp, Litopenaeus vannamei. Fish Shellfish Immunol 33:683-689.

https://doi.org/10.1016/j.fsi.2012.05.027 